\title{
EFFECTOR CELL-MEDIATED IMMUNE RESPONSE IN MICE IMMUNISED WITH SALMONELLA
}

\author{
ROHINI NAIR AND R. S. KaMAT
}

Department of Clinical Pathology, Haffkine Institute, Parel, Bombay 400 012, India

\begin{abstract}
SUMmARY. Effector responses of cell-mediated immunity were studied in mice immediately and 3 months after immunisation with different kinds of salmonella vaccine. Whereas immunisation with live Salmonella enteritidis generated delayed hypersensitivity and activated macrophages, immunisation with formalised vaccine generated neither. Although activated macrophages had declined considerably by 3 months after immunisation, the delayed-hypersensitivity response had persisted. It was possible to generate activated macrophages in these mice by stimulation with sonicate antigens of the immunising strain or Salmonella paratyphi $C$. Delayed-hypersensitivity responses were elicited in mice, immunised with live $S$. enteritidis, by sonicate antigens of the homologous strain, $S$. gallinarum or $S$. paratyphi $C$.
\end{abstract}

\section{INTRODUCTION}

The control of infections caused by facultative intracellular parasites such as Listeria, Salmonella and Mycobacterium is achieved primarily through immune or activated macrophages (Blanden, Mackaness and Collins, 1966; Mackaness, Blanden and Collins, 1966), generated as a result of effector T-cell/antigen interaction (Collins, 1974). Knowledge of the behaviour of these two cell types with time, after recovery from infection or vaccination, is important. Accordingly, effector cell-mediated immune responses were studied in mice immunised with different kinds of salmonella vaccine.

\section{MATERIALS AND METHODS}

Bacteria. S. enteritidis was isolated from naturally infected mice in the animal colony of the Haffkine Institute. S. gallinarum NCTC10532, S. typhi NCTC8385, S. paratyphi C, NCTC9325, Mycobacterium tuberculosis NCTC7416 (human type) and M. bovis NCTC5692 (var. BCG) were obtained from the National Collection of Type Cultures, Colindale Avenue, London NW9 5HT. Rough mutants of the strains of $S$. enteritidis and $S$. paratyphi C were obtained after repeated subculture in vitro.

Animals. Swiss white mice of appropriate weight, as described in each experiment, were used throughout. A representative batch of 10 mice from each lot was tested for delayedhypersensitivity (DH) response to a sonicate of $S$. enteritidis, and their sera were examined in agglutination tests with formalised $S$. enteritidis. If even one mouse showed a positive agglutination reaction, the batch was rejected. 
Sonicate antigen. Salmonellae from an overnight culture on nutrient agar, or mycobacteria from a 4-week culture in the medium of Doub and Youmans (1950), were suspended in phosphate-buffered saline (PBS), $p \mathrm{H} 7 \cdot 2$, killed by gamma radiation ( $2 \cdot 4 \mathrm{Mrad}$ ), washed in PBS and disrupted in a sonicator (MSE Ltd, Manor Royal, Crawley, West Sussex). The resultant material was centrifuged at $50000 \mathrm{~g}$ for $1 \mathrm{~h}$. Protein content was assayed by the method of Lowry et al. (1951), and appropriate adjustment made by dilution or by concentration after vacuum dialysis.

Immunisation. Swiss white mice (9-12 g) were immunised, as follows: (1) with five intraperitoneal injections of live $S$. enteritidis given at weekly intervals. Because the LD50 of the smooth strain of $S$. enteritidis was six colony-forming units (cfu), the first two injections contained, respectively, $c .10^{5}$ and $10^{7} \mathrm{cfu}$ of the rough mutant strain, and the final three contained, respectively, c. $10^{2}, 10^{3}$ and $10^{4} \mathrm{cfu}$ of the smooth strain of S. enteritidis; (2) three intraperitoneal injections of live $S$. paratyphi C containing, respectively, $c .10^{2}, 10^{3}$ and $10^{4} \mathrm{cfu}$, were given at weekly intervals.

In other experiments, mice ( $18-20 \mathrm{~g})$ were immunised with three intraperitoneal injections of formalised $S$. enteritidis (c. $10^{7} \mathrm{cfu}$ ) prepared as described by Dey (1964).

Delayed hypersensitivity was tested by the mouse-footpad technique of Gray and Jennings (1955). Bacterial sonicate, c. $50 \mu \mathrm{g}$ of protein, was injected into a hind footpad and measurements of footpad thickness were made $24 \mathrm{~h}$ before and $48 \mathrm{~h}$ after injection.

Microbicidal activity of peritoneal exudate cells (PEC). The assay of Blanden et al. (1966) was used. Each mouse was inoculated intraperitoneally with $c .2 \times 10^{4} \mathrm{cfu}$ of smooth $S$. enteritidis preopsonised with heat-inactivated rabbit antibody to $S$. enteritidis, and killed by cervical dislocation exactly 5 min later. Chilled Hanks's balanced salt solution (HBSS, $2 \mathrm{ml}$ ) containing $2 \%(\mathrm{v} / \mathrm{v})$ of heat-inactivated rabbit antiserum against heat-killed $S$. enteritidis, $10 \%$ (v/v) newborn-calf serum and $20 \mathrm{IU}$ of heparin, was immediately injected intraperitoneally into the mouse, the abdomen was massaged and the contents aspirated. The PEC from several mice were pooled and washed. The number of cfu of unphagocytosed bacteria in the washings was assessed. The washed PEC pellet was suspended $\left(c .6 \times 10^{6} \mathrm{cells} / \mathrm{ml}\right)$ in warm HBSS containing $12 \%(\mathrm{v} / \mathrm{v})$ newborn-calf serum; $1-\mathrm{ml}$ portions were incubated at $37^{\circ} \mathrm{C}$ for various periods of time and one portion was chilled immediately. After incubation, $0.1 \mathrm{ml}$ of saponin was added to a final concentration of $2.5 \%(\mathrm{v} / \mathrm{v})$ to lyse the PEC. Lysates were kept on ice until dilution and plating for the counting of viable bacteria. The percentage of organisms killed at each time point was calculated with reference to the number of cfu injected. When indicated, mice were stimulated by intraperitoneal injection of bacterial sonicate, c. $100 \mu \mathrm{g}$ of protein. Because sonicates of smooth salmonellae were extremely toxic to mice and those of rough mutants equally efficient in eliciting DH response in immune animals, sonicates of rough strains were used in these assays.

RESULTS

\section{Delayed-hypersensitivity response of immunised mice}

After immunisation with formalin-killed S. enteritidis, mice did not show footpad swelling even when tested 1 week after immunisation against sonicate of the homologous strain. On the other hand, when immunised with live $S$. enteritidis and similarly tested, mice showed good DH responses 1 week, and 3 months, after immunisation. The DH responses elicited by sonicates from smooth or rough strains of $S$. enteritidis were similar (table I).

\section{Microbicidal activity of peritoneal-exudate cells}

The PEC from normal mice phagocytosed and killed $c .10 \%$ of the challenge Salmonella in $5 \mathrm{~min}$ and $c .15 \%$ in $1 \mathrm{~h}$. The microbicidal activity of PEC was not much 


\section{TABLE I}

Delayed-hypersensitivity responses of mice immunised with $S$. enteritidis

\begin{tabular}{|c|c|c|c|}
\hline \multirow{2}{*}{$\begin{array}{l}\text { Immunising } \\
\text { preparation* } \\
\text { of } S \text {. enteritidis }\end{array}$} & \multirow[t]{2}{*}{$\begin{array}{c}\text { Time } \\
\text { (weeks after } \\
\text { immunisation) } \\
\text { of testing }\end{array}$} & \multicolumn{2}{|c|}{$\begin{array}{l}\text { Increase in mean footpad } \\
\text { thickness (mm) at } 48 \text { h elicited } \\
\text { by sonicate of } S \text {. enteritidis } \\
\text { from strain that was }\end{array}$} \\
\hline & & rough & smooth \\
\hline Formalised & 1 & $0.071 \pm 0.019+$ & $0 \cdot 125 \pm 0 \cdot 106$ \\
\hline Live & $\begin{array}{r}1 \\
12\end{array}$ & $\begin{array}{c}0.494 \pm 0.011 \\
\mathrm{ND}\end{array}$ & $\begin{array}{l}0.570 \pm 0.015 \\
0.569 \pm 0.020\end{array}$ \\
\hline $\begin{array}{l}\text { Control (non- } \\
\text { immunised) }\end{array}$ & $\begin{array}{r}1 \\
12\end{array}$ & $\begin{array}{c}0.071 \pm 0 \cdot 013 \\
\mathrm{ND}\end{array}$ & $\begin{array}{l}0.092 \pm 0.009 \\
0.183 \pm 0.023\end{array}$ \\
\hline
\end{tabular}

$\mathrm{ND}=$ not determined

* Details in Materials and methods.

$\dagger 95 \%$ confidence limits.

altered by intraperitoneal stimulation of mice with sonicate of $S$. enteritidis $36 \mathrm{~h}$ before the assay (fig. 1). The microbicidal activity of PEC from mice immunised with formalised $S$. enteritidis was similar to that of normal mice.

The PEC from mice, tested immediately after immunisation with live S. enteritidis, phagocytosed and killed $80 \%$ of the challenge organisms in $5 \mathrm{~min}$. However, in separate experiments, the PEC from mice, tested 3 months after similar immunisation, phagocytosed and killed a mean of $c .26 \%$ of the challenge organisms in 5 min and $c$. $33 \%$ in $30 \mathrm{~min}$. On the other hand, when mice were stimulated with $S$. enteritidis sonicate $36 \mathrm{~h}$ before the assay, the microbicidal activity of their PEC was greatly enhanced; thus, they phagocytosed and killed a mean of $c .73 \%$ of the challenge bacteria in $5 \mathrm{~min}$ and a mean of $c .78 \%$ in $30 \mathrm{~min}$ (figs. 1 and 2 ).

\section{TABLE II}

Delayed-hypersensitivity responses in mice immunised with $S$. enteritidis elicited by other salmonellae and mycobacteria

\begin{tabular}{|c|c|c|c|}
\hline \multirow{2}{*}{$\begin{array}{l}\text { Sonicate* } \\
\text { tested }\end{array}$} & \multirow{2}{*}{$\begin{array}{l}\text { Salmonella } \\
\text { serogroup } \\
\text { (O antigens) }\end{array}$} & \multicolumn{2}{|c|}{$\begin{array}{c}\text { Increase in mean footpad thickness }(\mathrm{mm}) \\
\text { at } 48 \mathrm{~h} \text { elicited in mice }\end{array}$} \\
\hline & & $\begin{array}{l}\text { immunised with } \\
\text { live } S \text {. enteritidis* }\end{array}$ & $\begin{array}{c}\text { not } \\
\text { immunised }\end{array}$ \\
\hline $\begin{array}{l}\text { S. enteritidis } \\
\text { S. gallinarum } \\
S . \text { typhi } \\
\text { S. paratyphi C } \\
\text { M. tuberculosis } \\
\text { M. bovis }\end{array}$ & $\begin{array}{l}\mathrm{D}(1,9,12) \\
\mathrm{D}(1,9,12) \\
\mathrm{D}(9,12) \ddagger \\
\mathrm{C}(6,7) \ddagger \\
\quad \ldots \\
\quad \ldots\end{array}$ & $\begin{array}{l}0.483 \pm 0.012 \\
0.450 \pm 0.010 \\
0.175 \pm 0.014 \\
0.375 \pm 0.019 \\
0.237 \pm 0.025 \\
0.245 \pm 0.032\end{array}$ & $\begin{array}{c}0.167 \pm 0.033 \dagger \\
\text { ND } \\
0.070 \pm 0.014 \\
0.037 \pm 0.034 \\
0.215 \pm 0.018 \\
0.235 \pm 0.025\end{array}$ \\
\hline
\end{tabular}

$\mathrm{ND}=$ not determined; $\ldots=$ not relevant

* See Materials and methods.

$+95 \%$ confidence limits.

$\ddagger$ These serotypes produced $\mathrm{Vi}$ antigen. 


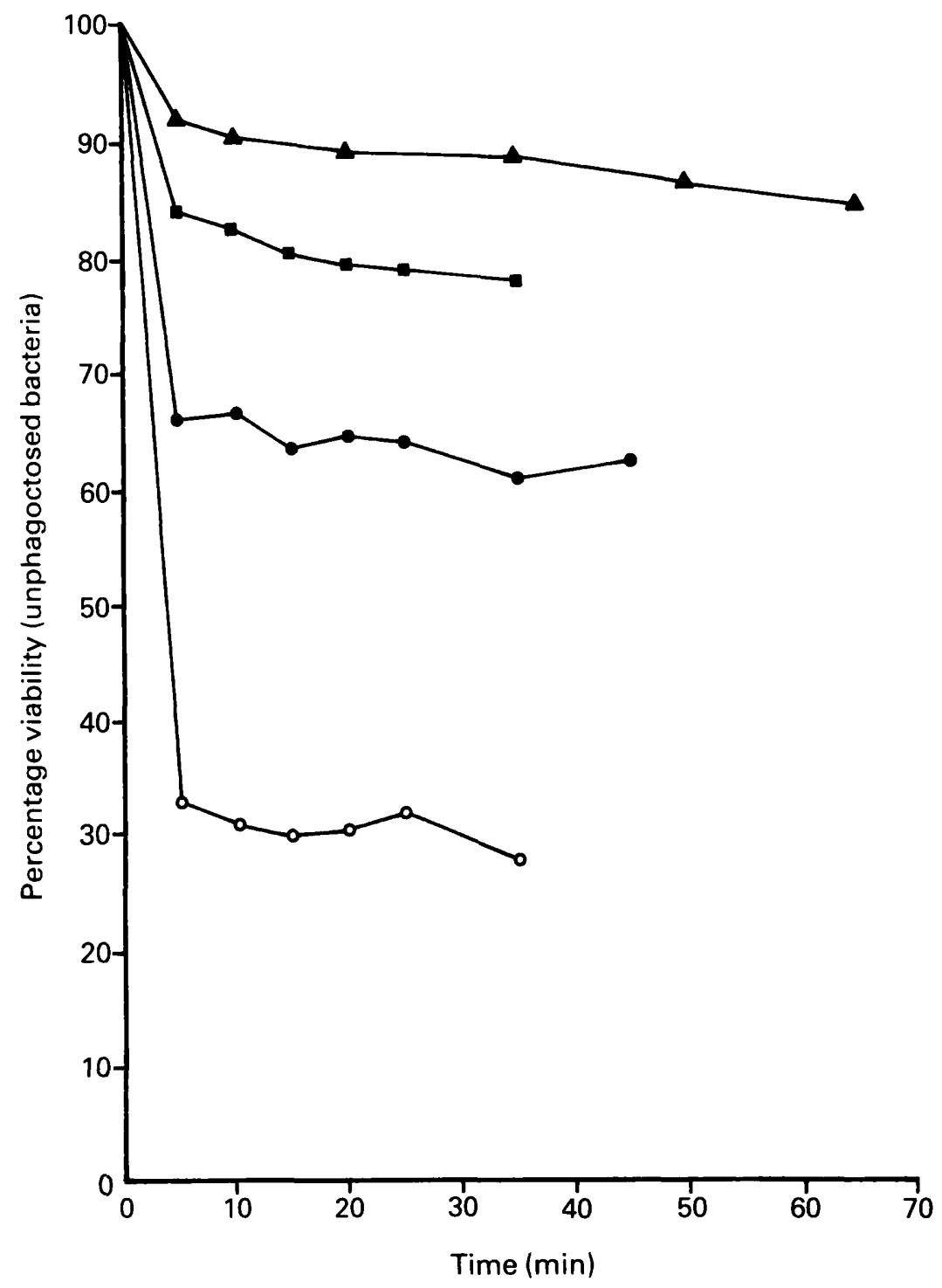

FIG. 1.-Microbicidal activity of pooled peritoneal-exudate cells from mice: not immunised but stimulated $(\triangle)$; immunised, 3 months before with live $S$. enteritidis, and stimulated $(\bullet)$, or not stimulated (O); immunised, 1 week before with formalised $S$. enteritidis, and stimulated (ם). Stimulation was with sonicate of $S$. enteritidis, $36 \mathrm{~h}$ before assay; see Methods.

\section{Cross reactivity between salmonellae of groups $C$ and $D$}

After immunisation with live $S$. enteritidis, mice were challenged immediately with sonicates of salmonellae of different $\mathrm{O}$-antigen types. DH responses were elicited by sonicates of each of the serotypes tested, viz., S. enteritidis, S. typhi, S. gallinarum and $S$. paratyphi C. However, sonicates of $M$. tuberculosis and $M$. bovis, similarly tested, did not elicit a DH response (table II).

DH cross reactivity was further studied by another approach. Mice, separately 


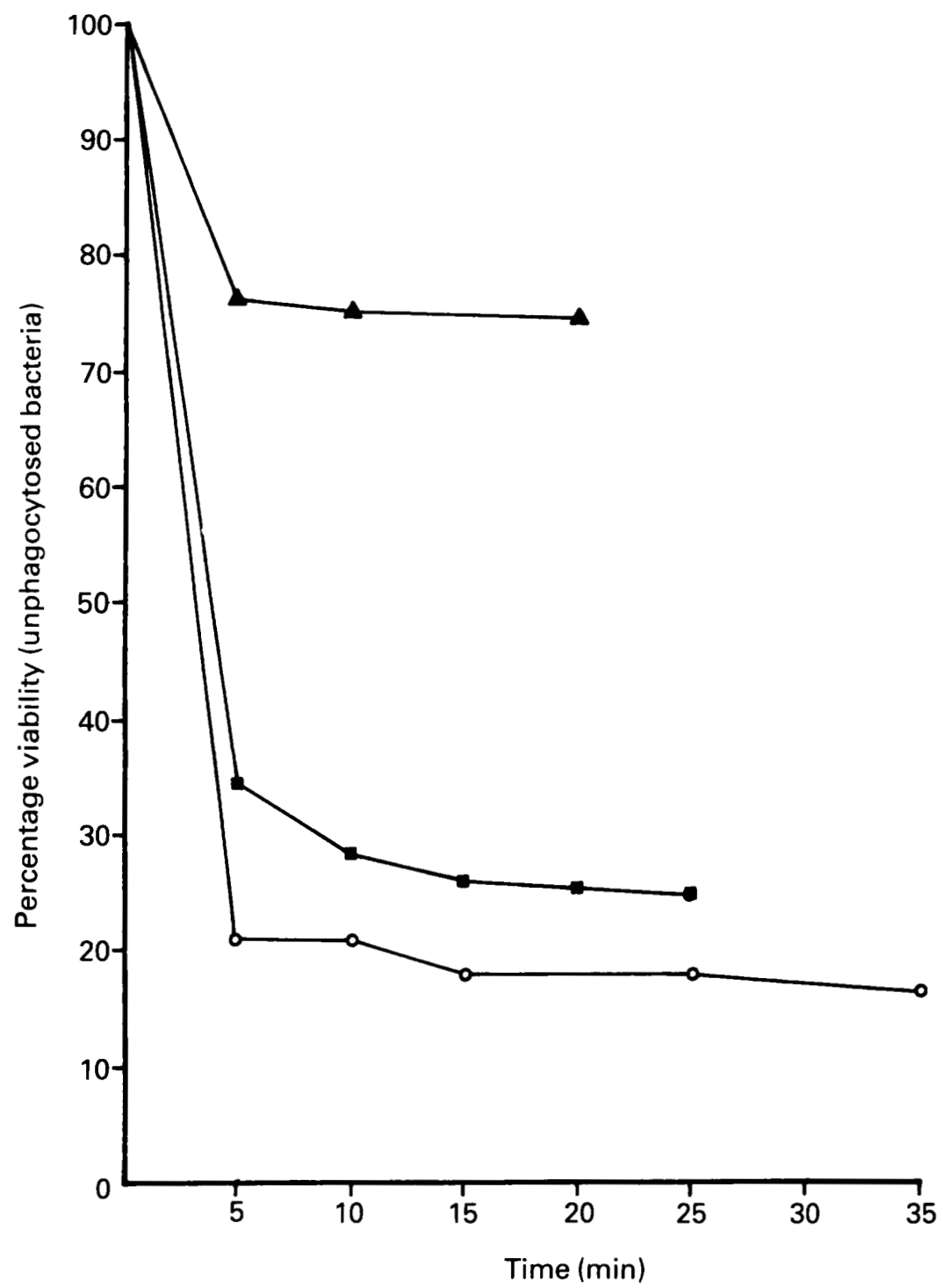

FIG. 2.-Microbicidal activity of pooled peritoneal-exudate cells from mice immunised, 3 months before with live $S$. enteritidis, and: not stimulated (४); stimulated with sonicate of $S$. paratyphi $\mathrm{C}(\boldsymbol{\square})$, or of $S$. enteritidis (O); see Methods.

immunised with live $S$. enteritidis or $S$. paratyphi $\mathrm{C}$, were tested immediately after immunisation for their DH responses to sonicates of each of the test organisms, one injected into each hind footpad. All animals gave positive $\mathrm{DH}$ responses to sonicates of the homologous Salmonella used for immunisation. Each of eight $S$. enteritidisimmunised mice responded to $S$. paratyphi C sonicate, whereas only one of five $S$. paratyphi $\mathrm{C}$-immunised mice responded to $S$. enteritidis sonicate.

Mice similarly immunised with live $S$. enteritidis, but tested 3 months after immunisation, showed good DH responses to sonicates of $S$. enteritidis and $S$. 
paratyphi C. Whereas PEC from unstimulated mice phagocytosed and killed c. $24 \%$ of the challenge bacteria in $5 \mathrm{~min}$ and $c .26 \%$ in $30 \mathrm{~min}$, those from mice stimulated by intra-peritoneal injection of $S$. paratyphi C sonicate phagocytosed and killed $c .66 \%$ of the challenge bacteria in $5 \mathrm{~min}$ (fig. 2).

\section{Discussion}

Because elimination of facultative intracellular bacteria is primarily achieved through activated macrophages (Blanden et al., 1966), the immune status of an animal to infections by these bacteria is related to the size of the activated-macrophage population. The decline in the microbicidal activity of PEC, observed 3 months after immunisation with live Salmonella, indicates that the activated macrophages have a short life span. They are nonspecific in activity (Blanden et al., 1966) and are incapable of spontaneous proliferation when urgently required.

In view of the persistence of effector $T$ cells at this time, as indicated by a positive DH response, the feasibility of rapid generation of activated macrophages, after antigenic stimulation without resort to fresh immunisation, was investigated and confirmed. The crude sonicate antigen used for stimulation contained lipopolysaccharide (LPS), which is known to be a stimulant of macrophages (Morrison and Ryan, 1979); as a result, the observed enhancement of the microbicidal activity of PEC may be due to the direct action of LPS. It can also be argued that the second antigenic stimulation is de facto a fresh immunisation. These arguments can be countered because the PEC of normal, non-immunised mice and those receiving formalised vaccine were not stimulated by the sonicate antigen.

Extensive cross reactions exist amongst Salmonella, and it was not surprising to find that shared antigens were capable of eliciting the DH response. Because $S$. gallinarum is nonflagellate and $S$. paratyphi $\mathrm{C}$ does not share any $\mathrm{O}$ specificity with $S$. enteritidis, it appears that the antigens involved in our test system are neither flagellar nor somatic antigens. Known antigenic relationships amongst the various serotypes of Salmonella of the Kauffman-White scheme (Edwards and Ewing, 1972) are based on somatic and diaphasic flagellar antigens. In view of our data indicating that neither of them was the antigen probably involved in $\mathrm{DH}$, the scheme may have little relevance to our understanding of cell-mediated immunity. The antigens involved might be fimbrial, or those of the cell-wall or membrane proteins. Another possibility to be considered is that the observed cross reactivity is due to a common antigen. However, when simultaneous DH tests were carried out in the same animal with homologous and cross-reacting sonicates, the latter did not elicit the response in every animal responding to the homologous sonicate, a finding that seems to exclude the involvement of a common antigen.

Even though the DH response is conventionally accepted as an index of cell-mediated immunity, rigorous proof that it is always accompanied by protective immunity is lacking (Mackaness, 1967). Hence, the ability of cross-reacting Salmonella to stimulate an activated-macrophage response in immunised mice was investigated and confirmed. It was unfortunate that sonicates of mycobacteria that did not show cross reactivity could not be tested because of technical difficulties related to lipids which interfered with the test system. Thus, the possibility that the observed "cross reactivity" was, in fact, a lack of specificity is difficult to rule out. This 
possibility is unlikely, however, because immunisation with live Salmonella, adequate for generation of the $\mathrm{DH}$ response, is an absolute requirement even for the homologous sonicate to stimulate generation of activated macrophages.

\section{REFERENCES}

Blanden, R. V., Mackaness, G. B. and Collins, F. M. 1966. Mechanisms of acquired resistance in mouse typhoid. J. exp. Med., 124, 585.

Collins, F. M. 1974. Vaccines and cell-mediated immunity. Bact. Rev., 38, 371.

DeY, N. C. 1964. Medical bacteriology, 3rd ed., Allied Agency, Calcutta, p. 468.

Doub, L. AND Youmans, G. P. 1950. Studies in tuberculosis chemotherapy. 1. Simple primary aromatic amines, in vitro and in vivo. Am. rev. Tuberc., 61, 407.

EdWARus, P. R. AND EwING, W. H. 1972. Identification of Enterobacteriaceae, 3rd ed., Burgess Publishing Co., Minneapolis, p. 213.

Gray, D. F. AND Jennings, P. A. 1955. Allergy in experimental mouse tuberculosis. Am. Rev. Tuberc., 72, 171.

Lowry, O. H., Rosebrough, N. J., Farr, A. L. and Randall, R. J. 1951. Protein measurement with the folin phenol reagent. J. biol. Chem., 193, 265.

Mackaness, G. B. 1967. The relationship of delayed hypersensitivity to acquired cellular resistance. Br. med. Bull., 23, 52.

Mackaness, G. B., Blanden, R. V. and Collins, F. M. 1966. Host-parasite relations in mouse typhoid. J. exp. Med., 124, 573.

MorRison, D. C. AND RYAN, J. L. 1979. Bacterial endotoxins and host immune responses. Adv. Immunol., 28, 293. 